\title{
學會
}

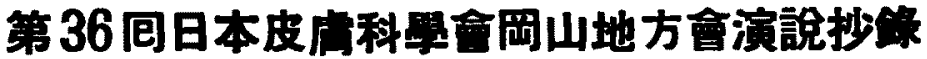

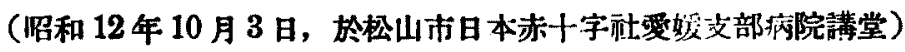

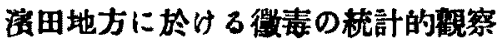

石天之楻君

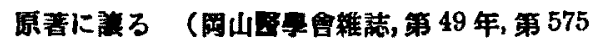
㩆に酸表の定了。

讯姓臭素疹の 1 例

$$
\text { 徳 重一志君 }
$$

思者国田某，只，53薜，初診 11 年 11 月 4 日 卵日入院，家族愿及ヒ躰往腚に就て特記すべきこ となし.

現病捱 本年 10 月 25 日副痛のため「サボニン」 なる筫慗を服用せるに1時間後より深紅色の疼痛

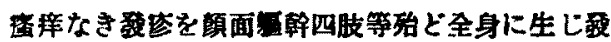

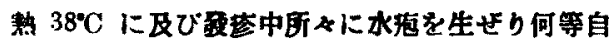
究定状なかりき第 3 日頃より肛門外陰部附近に

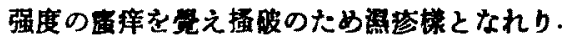

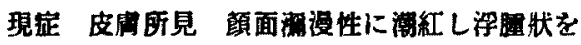

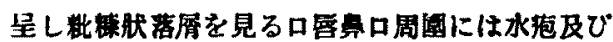

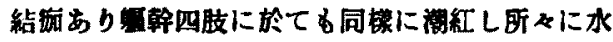
疮を見る肛門外陰部周園には水泡結的策闌面あり て稍く望再す。

診断「サボニン」は分析上奥素を主矵とす本证 は上記の病歷及び皮夙所見よりして奥素內服に灰

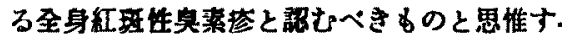

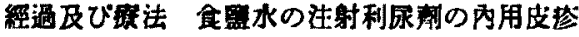

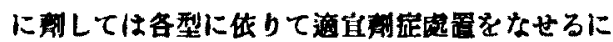
䧼度の色素沈着を眙して同月 21 日退院す。
涫 扣

前田興三郎君

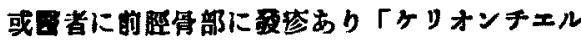

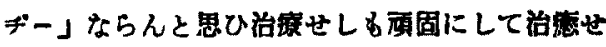
ブ京大に於でプローム翏」なりと云はれ京都一篮

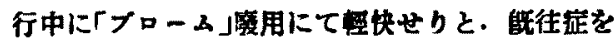
閣かさりしにより失敗せる 1 刚を追加す。

輸尿管結石の 12 例

堤 貞夫君

昭和 12 年 1 月より 8 月迄の間當敬宝にて坅断

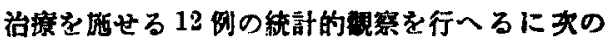

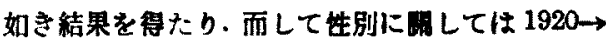
1928 年間の 10 㓭, 1920 $\rightarrow 1930$ 年間の 7 㫜, 1931 $\rightarrow$ 1934 年間の 12 测と今间の 12 到の合計に就て，又 㭧例に䌘しては中川，中西氏の 17 例と大道氏の

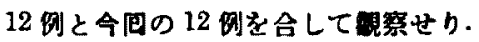

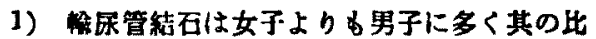
は4.1: 1 の割合なり。

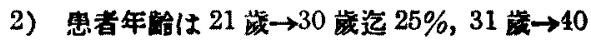
藏 $25 \% ， 41$ 藏以上 $50 \%$ なり。

3）㥁者側は右側 $(56.1 \%)$ ，左侧 $(36.6 \%)$ ，雨 侧 (4.9\%)，不明 $2.4 \%$ の割合なり。

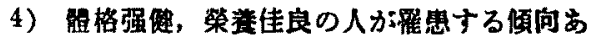
b,

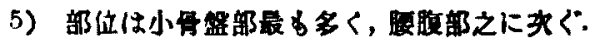

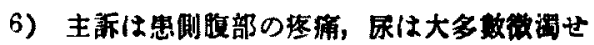
n. 
7) 2 侧に於て器熱を訴人大多数は無熱なり。

8）姑息療法も施さず結石自然排出せしは 2 肕 tb.

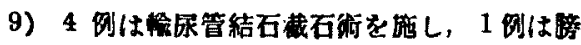

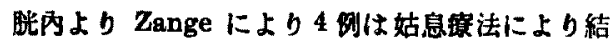
石自然排出を見，結果良好なりき。

追 加

$$
\text { 小池軣太郎君 }
$$

或突费に到士る年跲的网係，男女の性による频

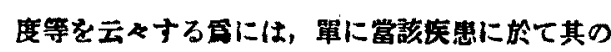
表面に現はれたる数字的開係のみに搭らナ゙して，

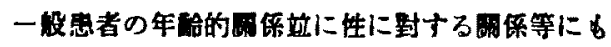
同時に考虑に入るぺものと思惟す。

追 加 本賀访堆君

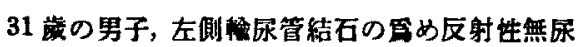
峜を起せる定测を追加せり，本刚は手街後に死亡 せり.

母子に覆生せる Mibelli 氏被仵血管: 腫に就て

$$
\text { 黑山察吾君 }
$$

余は昭和 12 年 8 月 2 日 Mibelli 氏被角血管腫

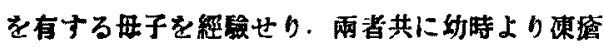
に燐り結核性の疾病に羅りしことなし．Priquet，

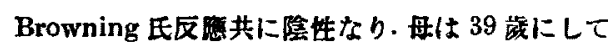
農業をなし雨手留及び提留，手指の腹則，足背に

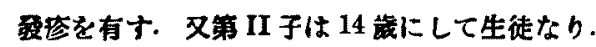
勫 3 年前上り左手揎全部，右手掌，右手第 II, III，

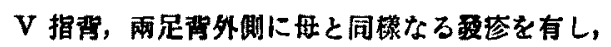

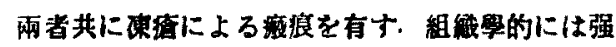
度の角化定と表皮及び踭屈に於ける血液を以て 充されたる空洞形成なり、父滕に於ける維細な

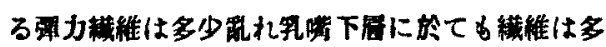

少断裂して不本等となつてるろ. 併し此等は整度 なり.

\section{井出反應に就て（第2 報）}

$$
\text { 前田哲夫君 }
$$

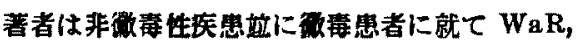

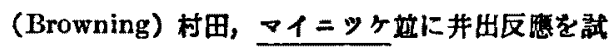
み夫れ等の敏感度と非特異性を比较し，就中，并

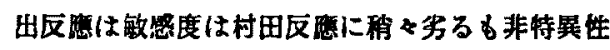
少き事を述ぺたり、詳細原著に鿁る。

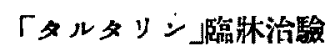

$$
\text { 前田哲夫君 }
$$

著者は內服「アクチソ゚ール」注射用「てクチゾー ル」及び外用「タルタンン」の治騟成縝に就て述一

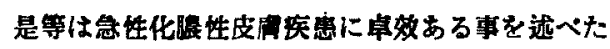

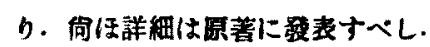

追 加

$$
\text { 山本春海君 }
$$

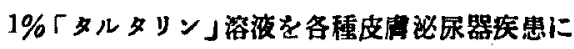

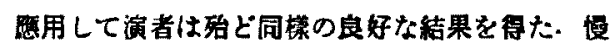

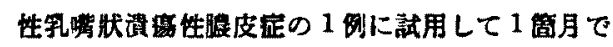
そを全治せしめた。

$$
\begin{aligned}
& \text { 腎臟結稯二於ケル「ビエログラム」 } \\
& \text { 研究一（第 } 2 \text { 報) } \\
& \text { 汇原 敏 夫君 } \\
& \text { 融井朋安君 }
\end{aligned}
$$

追て原著として蛋す可し.

$$
\begin{aligned}
& \text { 「サルバルサン疹」の } 2 \text { 例 } \\
& \text { 江原 敏 夫君 }
\end{aligned}
$$

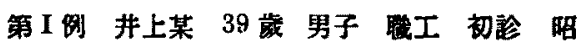

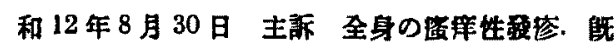
往歷 昨年 3 月右陰蕉根に括破泿を生じ 3 日後台

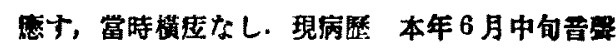




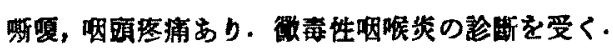

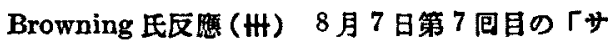
ルバルサン注射」後全身供总熱感あり，暜日指趾

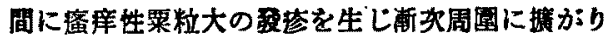

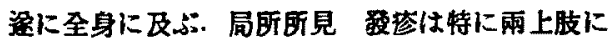
著明にして粟粒大紅色丘垮，所心沉㜊性境界不明

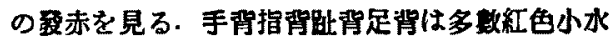

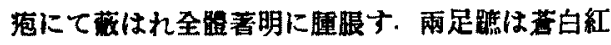

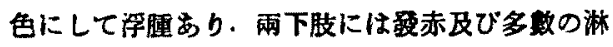

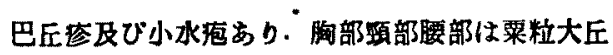

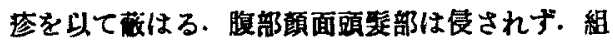
饿學的所見 冥皮部に於て僅の不全角化を見る。

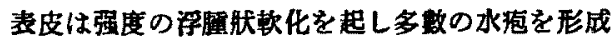
ナ. 水泡內容は㮖の白血球及びフイブッン橴」物

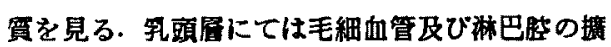
張と其の周圍の細胞浸调を見る. 第 II侧 小璠 某 33 藏農業 初晾昭和 12 年 6 月 7 日 主

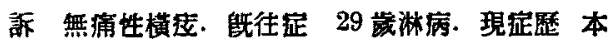
年 5 月 2 日感染の機會あり。同月 20 日頃無凊性

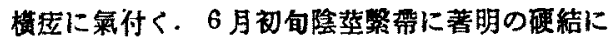

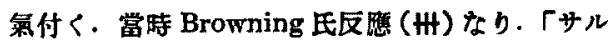
バルサン都」2 號 1 回, 4 號 12 回,「ベルビスモー ル」8回，「ミラノイエン」8回注射を受く、8月 6 日最後の「ルバルサン」注射後約:5 時間にして指

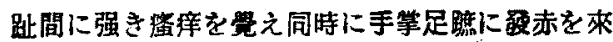
ナ. 約 5 日㳇より同部の皮漏肥厚し來り所《に深

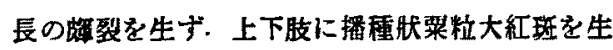
し堛择强し. 局所所見 手掌指內面及び足蹠は强 度の肥厚角實にて蔽はれ所ょに大小の知裂ちり。

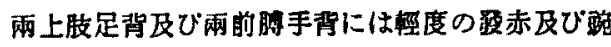

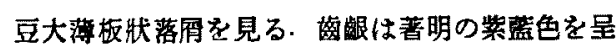

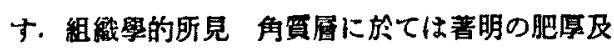

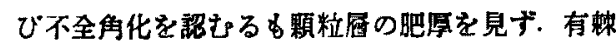
居は㯨度の浮嗹を來し 2-3 白血球の遊走せるを

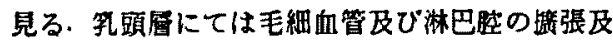

び周圍に輕度の淋巴球の浸潤むるを兒る。

追 加

永井政 忠君

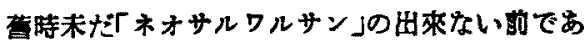
つて「サルワルサン」今で申すと「曾サルワルサン」 と云ふのであり，之を 0.5 苛性加里にて中和し攵 溜水 $300.0 \mathrm{cc}$ に溶解して注射したるに4一5 日に

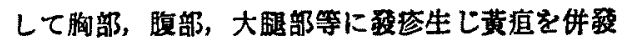

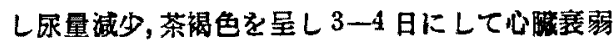

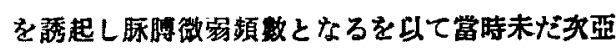
硫酸曹澾なきため $0.9 \%$ 食曥水を $100.0 \propto$ 注射せ

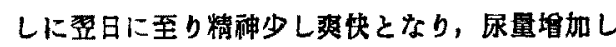

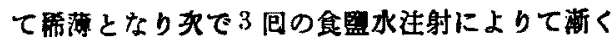
役装む消失に傾き尿色稀海となり全治するを得た り.

追 加

$$
\text { 新江陽 君 }
$$

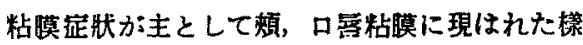
に僅か 2,3 㑚ではあつたが記憶してるます。

追 加

清 水 政 男君

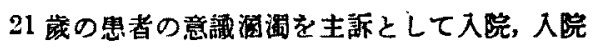
時の診断不明にして翌日患者の意誐を饭復すると 同時に「サルバルサン」注射を施行せられてより約 2 時間後䟚吐，惡心を以て意価消失せしを報し，

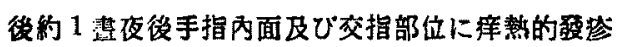
を生じサルバルサン」注射による中等定肰なるを 認めたり

$$
\text { 「ナトロフクキバルサン」治驗 }
$$

向畑十四郎君

日曹の 1 新驅微新「ナトロアクチバルサン」を用

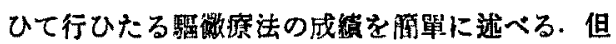
治驩刚未僅少にして的確なる制断を下し得るに至 らざるを筫域とする。 
本劑は第 1 期及び第 2 期微毒の如く比較的早期

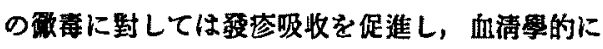

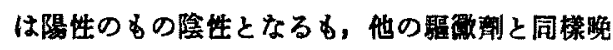
一期微毒に璟しては血清學的复動を見ること困難て ある。

副作用に就ては，本剖は其の慗浩に際し副作用 著起の缺點を除去すへく注意されてるるに不拘本

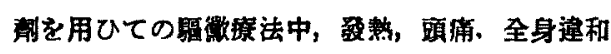
の如き副作用を見る。

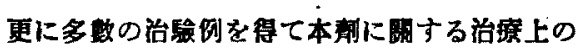
值を捡討することとする。

\section{先天性輸尿管の渏形に就}

榙英基君

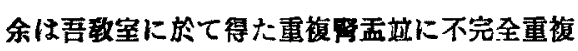
输尿管の 6 侧を報告し太.内男 5 例，女 1 例. 重

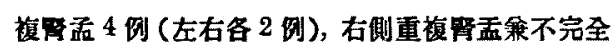

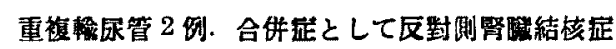

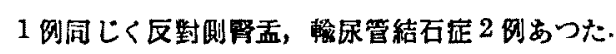

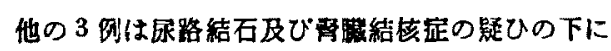
Pyelogrophie を施行したのであつたが異常を証 めなかつたるのである. 余の定例に於ては完全重

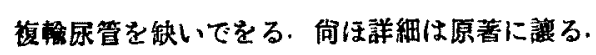

Perbismol の治驗例 榙英基君

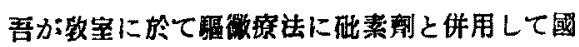

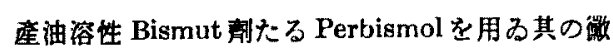
毒血清反應の移動及び副作用を30例に就て調查

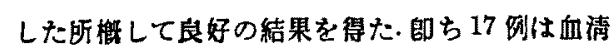

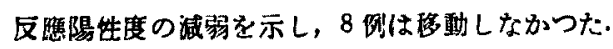
5 例は初期硬結で最初より血清反㫫は陰狌，又第

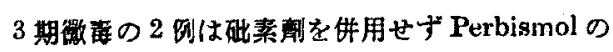
みを用ひたが血情反㮣の移動はながつた，副作用 として Bismutsanm 2 侧生じた他は何等の踶狀を も併砺しなからた。
追 加 小池藤太郎君

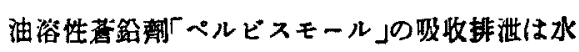
溶性のひのに比才れば造に悢漫なれどもっだフロ ン」「ミラノイエン」等の「荅鉛メムルジオン」に 此す扎は速なり．余は此事赛を顯微化學的に證明 ナる事を得をり。

稀有なる包皮內結石の 1 例

伊 藤 誠 硬君

患者岩谷某 40 紫農業初趁昭和 11 年 12 月 22 日

拼尿障碍及び陰茎繫帶部に於ける硬結を新ふる

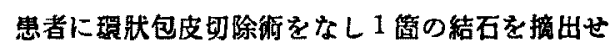
๖. 剔出結石は形狀隐元豆に類し扁本短棓圆形を 呈し灰白色にして貿硬く，重望 $0.564 \mathrm{~g}$ ，長徑 1.24 $\mathrm{cm}$, 短佂 $1.05 \mathrm{~cm}$, 厚さ $0.62 \mathrm{~cm}$ なり.切断面は同 心性の軨層を認め，化學的分析の結果は宸酸石灰，

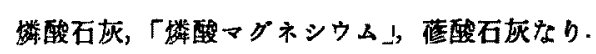

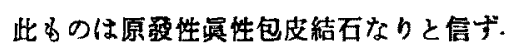

興味ある尿道㽞室結石の 1 例 伊藤 喴 爾君 患者は 40 藏の男, 職業は朢業, 初診は昭和 12 年5 月 12 日

28 藏の時に尿道淋にかからし患者, 最近淋疾の 再發を見，此急性尿道淋の經過中に尿道憇等內に 結石の存在せるを知りたり，依て之を剔出す，剔

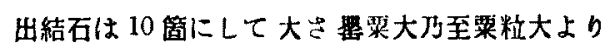

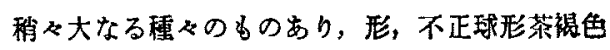

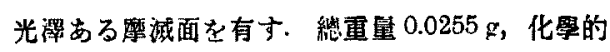
分析の結果蓝酸石灰, 燐酸石灰, 「燐酸マグネシウ A」なり.

胳胱三色部羽装状形成の 1 例に就て 大造峰雄君

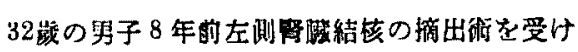


たり、爾熖何等障碍なくして今日に至りしが本年 6 月初甸全 1 日中放康に漈して血尿を証めしかば 當科を訪れたり，勝肬繶榆查の結果 8 年前の膀胜 鏡所見として雨㑡尿管口附近に多数の小結核性

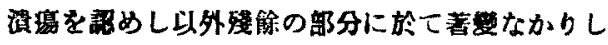

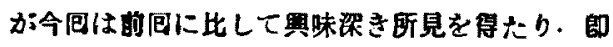

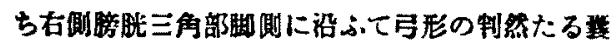

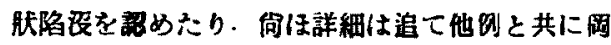

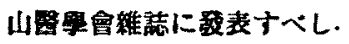

Réthragine の治驗例

\section{西川規夫君}

著者は佛國 Toruude 會社の㱔品 Réthragineを 9 人の麻毒性尿道奖患者に使用し5 测に於て好結 果を得な。

皮虔電解算に就て 西川規夫君

Originalに䜋る。

流血中蹎菌の 1 檢出法

難 诐政士君

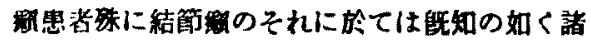

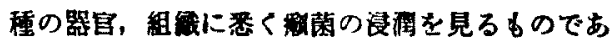

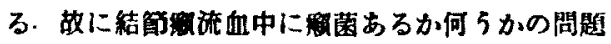

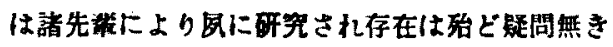

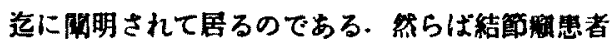
血渡に如何なる最に於て籍菌が見られるのである

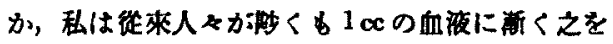

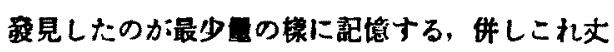

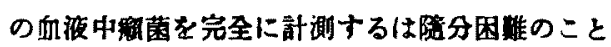
であるから、「アンチフォルミン」により同賀化し たり或仙醋酸を用ひ办血球を破城し，それを遗心 沈晸し或は更に「アンチフォルミン」を何かし沈漫 して沈造中の菌を計則したのであるが，此際同貿 化したるらのに於ては践菌が何れの部，何れの細

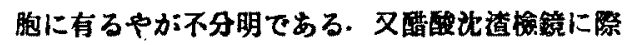
してる量が大量なる命に之を篮く見ることは非常 に時間を娳ナるの缺點があるのである.

私は可成㒖少量の血液中に菌を見んとした：其

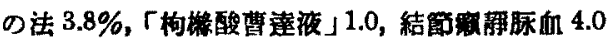
を注射器に取りよく混合して之を內容0.05の毛細 管內に服取し之を垂直に立て24 時間福置するの である.此绦赤血球仁毛細管の下牛部に沈设し， 其の上に白血球居が物 $1 \mathrm{~mm}$ 位の厚さの白色の居 を仅るののである. 这に於て其の境界を切断し， 赤血球局は其の下端より波肰に,「オプェクトクラ

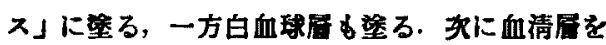

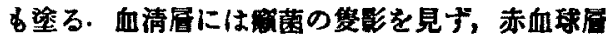
にては丹念に求むるる始ど見得なかつたり白 血球㞒に於て大部分中性白血球及び「モノチーテ ン」の內部に哙菌されて存在せるを覆見したので

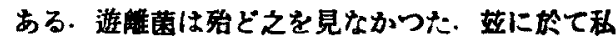
は鯂菌は單に理學的に白血球と比重か洞しなるに よりて此局に多き中，若くは血球生理的吸橥力

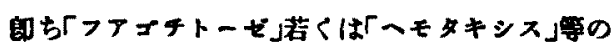

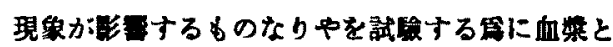

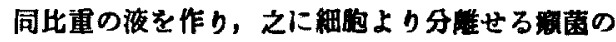

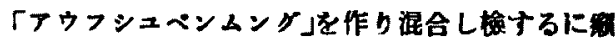

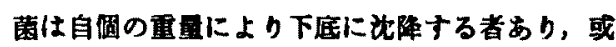
は途中に遊走ナるものあり，故に菌が自血球展 に最す多きは白血球生理的喰菌機能によろるので あり，恐らくは此現禹は流血中の菌，其の他あ らゆる微生物等にも通有ナるすのであら5.結論 として (1) 結第圊の血渡中には 0.04 位の量にて

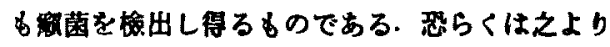

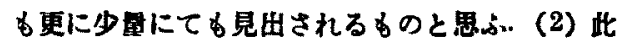

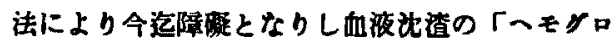

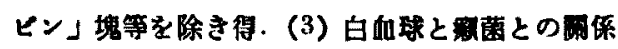
を明膫ならしぬた，中姓白血球どチーテン」に 喰はれ，淋巴球は開興せず（4) 吾人は此法を以 
て他の「バクテリェミー」にる用し得るすのであ

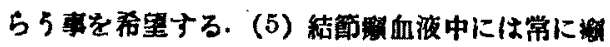

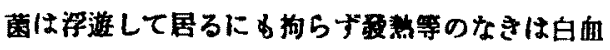
球に包檟せらるる篇ではなかららか。

槴 加

$$
\text { 根 紫溥君 }
$$

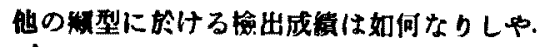

$$
\text { 追加野島泰治君 }
$$

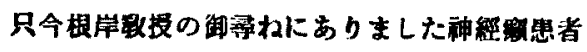

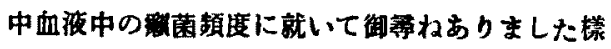
でありますがこれに就いて私共の考へを追加致し

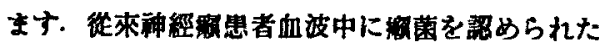
と云ふ例は多くは病型を謂つて取报つたために原 因ナる禁に思ふのであります。

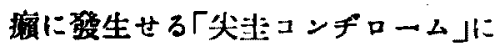

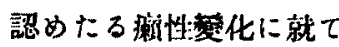

守屋篮夫君

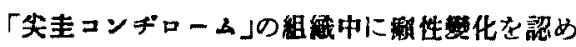
たる刉は末だ其の報告がない。著者は今回偶然大

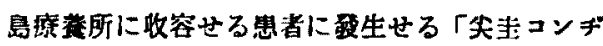

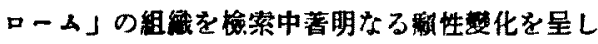
たる與味むる1则を經龭したるを以て其の样絴を 遮に般告せんとす。

患者 星OマO \& 24 藏 中等度結節燔

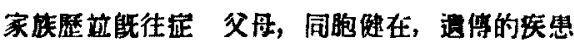

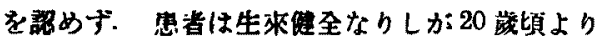

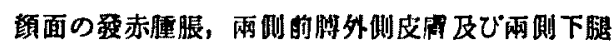

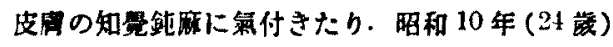
春頃より頋面，四腊に踠豆大乃至小捍頭大の結節 を生したり，地方罢師により解の祄断を受け昭和 10 年 6 月 5 日當所に敢容せられたり。

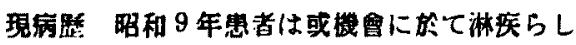
く思はるる族氧に䖽患せることに氣付きたり．即
ち排原時の疼痛及び多量の白带下の生じたるる゙認

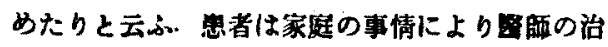

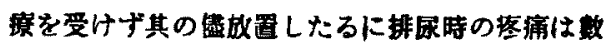
莮間にして自然消失したるる白带下は就として 減せす今日に至る汽多量を出すと云ふ。昭和 9 年 末比に至り患者は江門周国に2,3 筒の米粒大の证

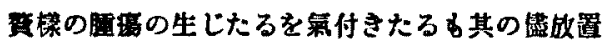

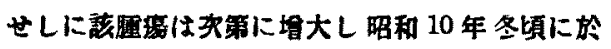
ては指頭大乃至拇指大となり步行に際し堪一鹤き 疼桶を感ナ゙るに至れり。

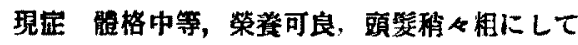

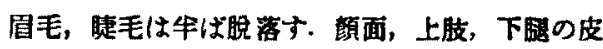
周には散在性に垸豆大乃至指頭大の結節存在する を見る当兩手指，雨足趾の運動箱㾝を諗めず，肉

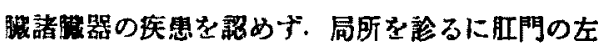

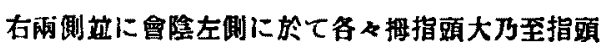
大の爾堭 1 简づつを見る，其の中最大なるるのは

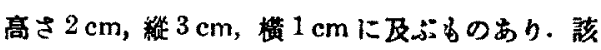

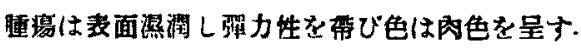

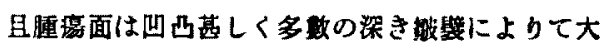
小不同の肉塊に分裂寸，併し各肉塊の表面は更に

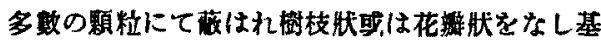

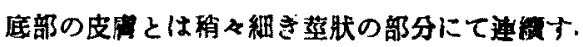

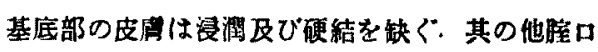

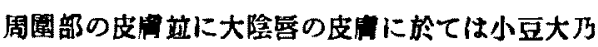

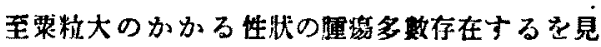

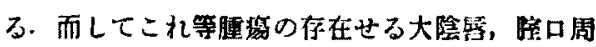

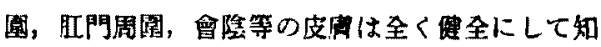

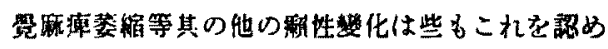

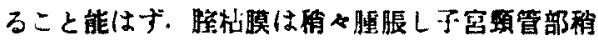

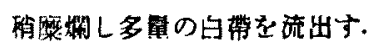

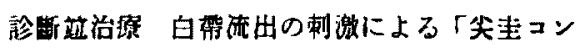
ダローム」なる部断の下に昭和 10 年11月27日手

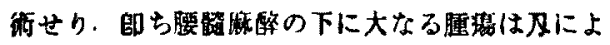

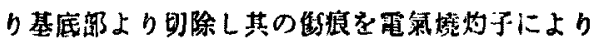


て㛥灼し小なる堙爆は其のまま燒灼して手術を終

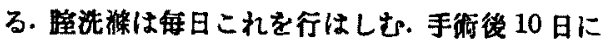
して創傷䈍え白带は減ぜざる患者は悬びて病室 より退出したり。

「尖圭コンデローA」の組䋐所見 䫛销鏡標本に 慗作してズダンIII」「へマトキシリンヨージン」, 「チールーマトキシタン」,「チールニールセン」, ワイゲルト氏法，・ロリー氏法等の染色方法にて

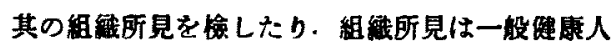
に於ける「笑圭コンデローム」の所見と甚だ相似

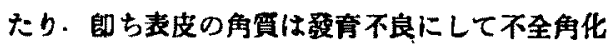
をなせる部分あるる網肤㞓は蓄しく增殖して網㹜

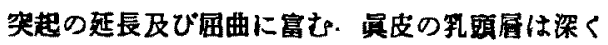

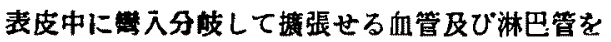

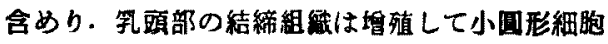
の浸润著明なり，而して本则に特有なるは等稫部

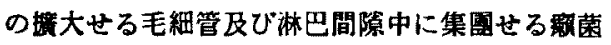

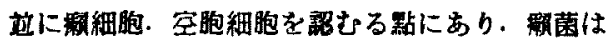
㴶匹の集圈をなして散在性に存在し彩細胞，空胞 練胞は多教存在才。

之を要するに本例は「笑圭コンデローム」周圍の

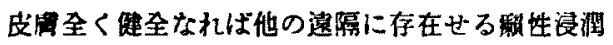

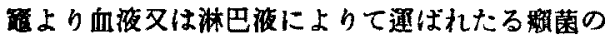
「垁圭コンヂローム」中の膘大せる豚管部に於て沈 着し颗性變化を惹起せるものなりと思考さる。

線狀皮膚炎の 1 例

早田晧君 本定は大正 6 年致旭致授により初めて仅表され た1種の皮周炎で其の病源は「アシバアリガタ 、 ネカクシ」の整僬に因るのである・去る9月初旬 長島管生園の 1 職員の左湖的膊に定型時の本定を 見た。

追加平贺势雄君 松山にを有るらしく私名4-5 刚の夫机を見た。
追 加

小池藤太郎君

余は第 35 四當地方會に於て同山地方に於ける 本筷患の第 1 例を表せしが，頃日更に第 2 例(27

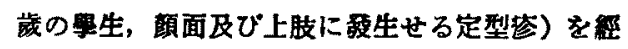

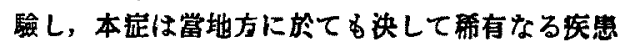

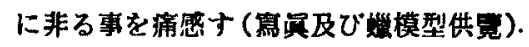

臨林頊談

小池藤太郎君

1.篓睡睤を体へる Pringle 氏病

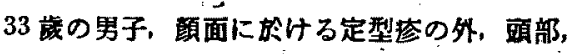

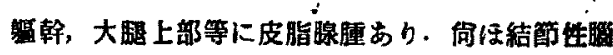
硬化定を合併す，本阿に於て特に興味ある事は更 に专腫暨を合併せる點にして，如斯は余の知れる 的国に於ては東西交新に未だ其の記载を見ざるが

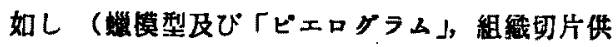
覧).

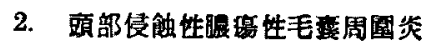

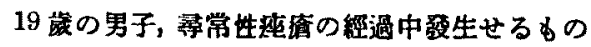

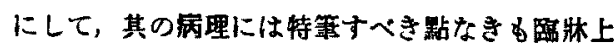

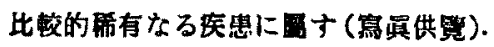

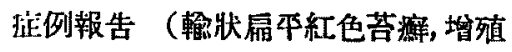
性天疱療, 珊的樹狀結石)

平賀芳 雄君

1) 䡫㳀扁平紅色苔解の 1 例

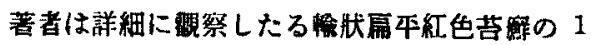

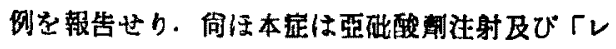
ントダン療法」にて险快せり．

2）增殖性天疮嗐の 1 们

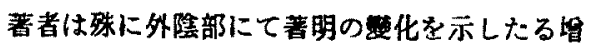
殖性天疮痛の 1 例を詳細䘽察して報告せり．晌任 本应は「ビタミンの」注射の行中に輕快せるは 注目すべきなり 


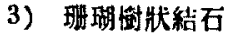

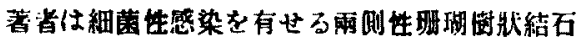

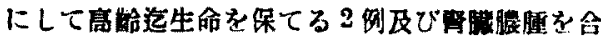
併せる左側田䑏結石にして手街後死亡せる 1 则を

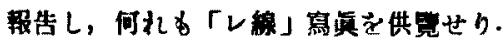

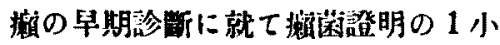
手政

野岛垃 治君

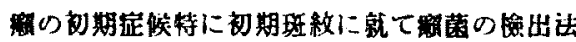
を述一，小林氏が睪丸中の菌語明に用ひ心る易

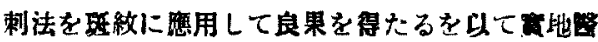

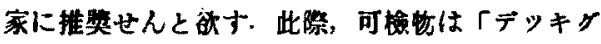
ラス」に染抹「チチールガベット」の染色に际し て水洗は「ビーカーう中の水中にて「デッキ」を

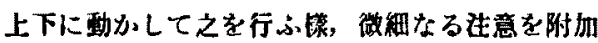

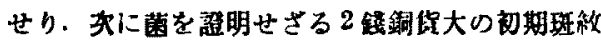

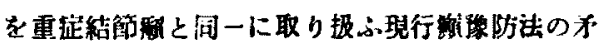

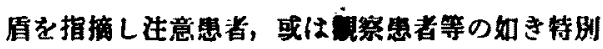

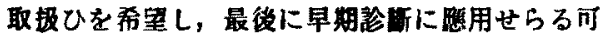
き夸考反憼に就ての意見を逑べたり。

軨尿管結石標本供覽

前出與三蚛君
刚を垠告せり．其の內男子 42 测，女子 8 例なり．

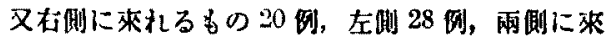
れるすの2明なり。

垖 玔

$$
\text { 根 鉴博君 }
$$

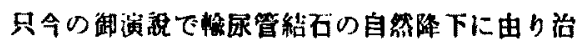

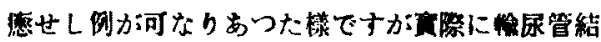
石は可なり大きなるのも自然に又は旸㙩に作つて

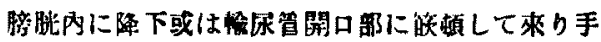

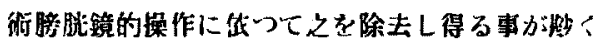
な⿻.

余が考策せる交叉㹕に就て

$$
\text { 永眡政忠君 }
$$

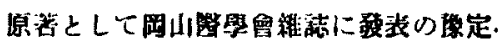

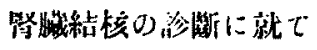

$$
\begin{aligned}
& \text { 根岸博耕 } \\
& \text { 汇原敏夫活 }
\end{aligned}
$$

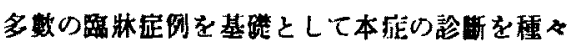
なる方面より祭祭せしすのなり第2 報を阱せて原 著として影表才可し。 